\begin{tabular}{|l|l|l|}
\hline \multicolumn{2}{|c|}{ PublisherInfo } \\
\hline \hline PublisherName & $:$ & BioMed Central \\
\hline \hline PublisherLocation & $:$ & London \\
\hline \hline PublisherImprintName & $:$ & BioMed Central \\
\hline \hline
\end{tabular}

\title{
Osteoprotegerin reverses osteporosis and prevents vascular calcification
}

\begin{tabular}{|l|l|l||}
\hline \multicolumn{2}{|c||}{ ArticleInfo } \\
\hline \hline ArticleID & $:$ & 149 \\
\hline \hline ArticleDOI & $:$ & $10.1186 /$ ar-2000-66847 \\
\hline \hline ArticleCitationID & $:$ & 66847 \\
\hline \hline ArticleSequenceNumber & $:$ & 106 \\
\hline \hline ArticleCategory & $:$ & Paper Report \\
\hline \hline ArticleFirstPage & $:$ & 1 \\
\hline \hline ArticleLastPage & $:$ & 3 \\
\hline \hline & & RegistrationDate : 2000-9-20 \\
\hline ArticleHistory & $:$ & OnlineDate \\
\hline \hline ArticleCopyright & $:$ & Current Science Ltd2000-9-20 \\
\hline \hline ArticleGrants & $:$ & \\
\hline \hline ArticleContext & $:$ & 130753311 \\
\hline \hline
\end{tabular}




\section{Keywords}

Atherosclerosis, calcification, osteoporosis, osteoprotegerin

\section{Context}

Osteoprotegerin ligand (OPGL) expressed on the surface of osteoblasts plays a crucial role in the formation and activation of osteoclasts by binding to receptor activator of NF-?B (RANK) on the surface of osteoclasts and their precursors. OPG, a secreted protein, binds to OPGL and prevents its interaction with RANK, therefore reducing bone resorption. Overexpression of OPG in transgenic mice results in osteopetrosis, but without defects such as impaired tooth eruption that are seen in other murine models of osteopetrosis, for example the op/op mouse. By contrast, OPG-deficient mice have decreased bone density, but also develop calcified arterial lesions. The aims of this study were to further characterize the OPG-transgenic mouse and to determine whether OPG can prevent the osteoporotic phenotype in $\mathrm{OPG}^{-/}$mice.

\section{Significant findings}

OPG-transgenic mice exhibited decreased osteoclast number and activity in the endosteum, but not in the periosteum, which could account for the phenotypic difference between this and other murine models of osteopetrosis. Possible explanations for this effect are that OPG is specific for endosteal osteoclasts, or more likely that the amount of OPG expressed is insufficient to completely block the high levels of OPGL in the periosteal envelope. OPG-transgene-expressing $\mathrm{OPG}^{-/-}$mice reverted to an osteopetrotic phenotype, similar to that of transgene-expressing wild-type mice. They did not develop the arterial calcification associated with the $\mathrm{OPG}^{-/-}$mice (although injection of OPG into adult $\mathrm{OPG}^{-/-}$ mice had no effect on preexisting calcification). The latter observation indicates that the OPG/OPGL/ RANK pathway plays an important role in pathological calcification.

\section{Comments}


This interesting work extends our understanding of the role that OPG plays in bone, and offers an explanation for the intriguing phenotype of the OPG-transgenic mouse. More importantly, the data suggest that OPG could be a realistic anti-resorptive therapy with the potential added benefit over other therapies of preventing arterial calcification associated with osteoporosis. Although OPG did not appear to reverse the calcification process, further work should clarify whether it can arrest further progression of vascular calcification and shed light on the role that the OPG/OPGL/RANK pathway plays in this process.

\section{Methods}

OPG-deficient mice, transgene expression

\section{References}

1. Min H, Morony S, Sarosi I, Dunstan C, Capparelli C, Scully S, Van G, Kaufman S, Kostenuik P, Lacey D, Boyle W, Simonet W: Osteoprotegerin reverses osteoporosis by inhibiting endosteal osteoclasts and prevents vascular calcification by blocking a process resembling osteoclastogenesis. $\mathrm{J}$ Exp Med. 2000, 192: 463-474.

This PDF file was created after publication. 